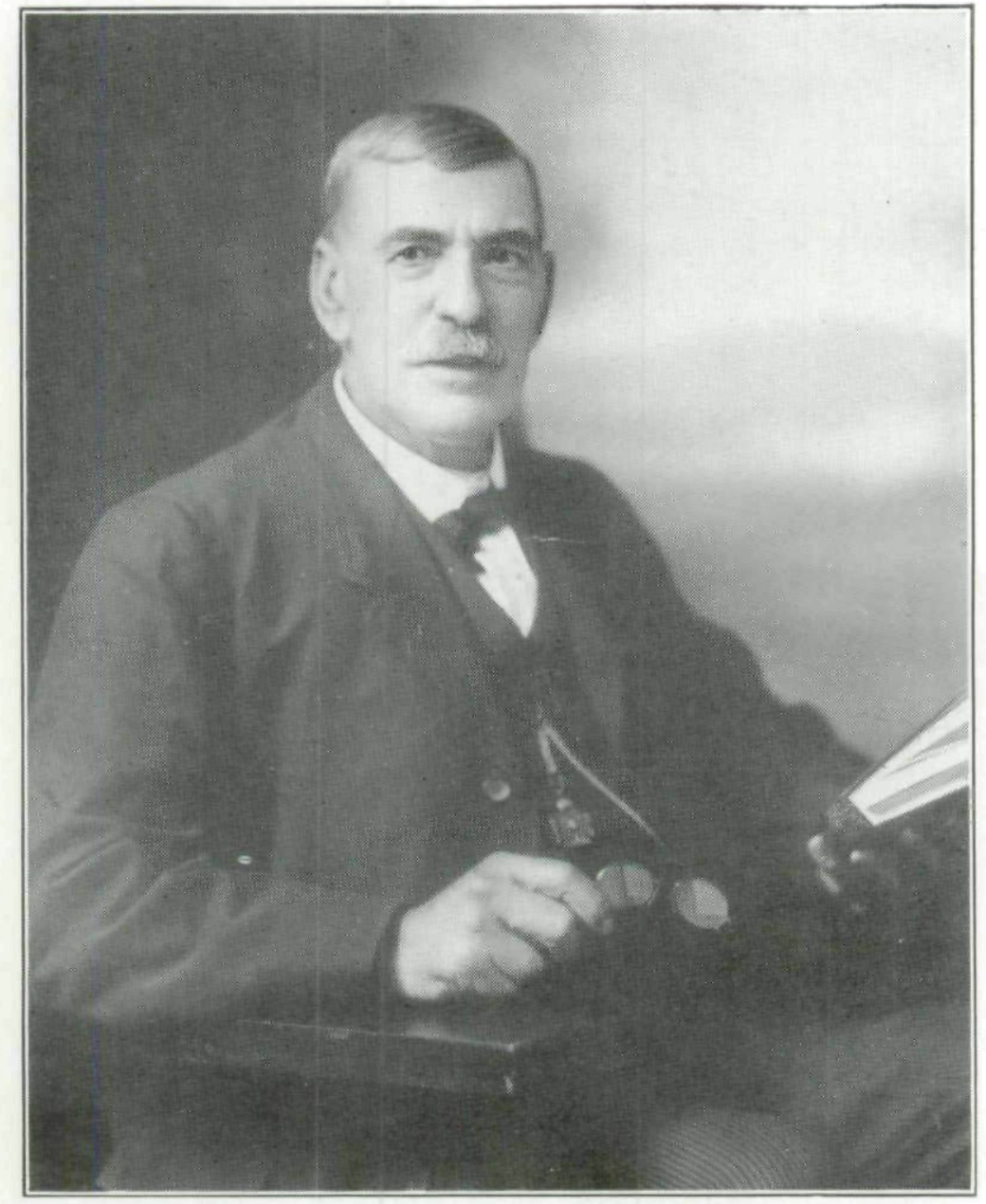

CAPT. W. A. DUCKWORTH 


\section{ESCAPE OF IOWA SOLDIERS FROM CONFEDERATE PRISON.}

BY CAPT. W. A. DUCKWORTH.

In the fall of 1863 , Gen. Banks, in whose Department was the Thirteenth and Nineteenth Corps, received orders from Washington to penetrate into Texas. General Ord, who commanded the Thirteenth Corps, direeted General Herron to establish his division at Morganza to observe the crossings of the Atchafalaya River, and hold Confederate General Green in check. General Herron sent Colonel J. B. Leake, of the Twentieth Iowa, with the Nineteenth Iowa, the Twenty-sixth Indiana Infantry, and 250 eavalry to Stirling's farm, about nine miles from Morganza. The following account of this engagement is quoted from "History of the Civil War in America," by the Compte de Paris :

On the evening of the 28th of September Green secretly crossed the Atchafalaya River with three brigades of infantry and one of cavalry to surprise a portion of Colonel Leake's brigade. . . . Leake had posted himself, with two regiments of infantry (the Nineteenth Iowa and Twenty-sixth Indiana) numbering about six hundred men and two cannon, at two miles from Morganza. He had placed his two hundred and fifty cavalry, under Major Montgomery, more to the westward, near Atchafalaya. Green, sending Major Boone against the latter, with a regiment of cavalry, and Mouton's and Speight's two brigades of infantry, direct against Leake, had taken a circuitous route with the rest of his troops to attack the latter in the rear and place himself on his line of retreat. Boone, being the first to attack, separated the Union cavalrymen from Leake's troops, and pushing them in disorder in another direction, did not permit them to give Leake the alarm.

At the same time, Speight, followed by Mouton, marched rapidly and fell unexpectedly on the Federal infantry. The latter, surprised and hastily drawn up, defended itself energetically. But Boone's cavalry, arriving on its flank after their first success, threw its ranks into disorder, and, not even giving Mouton time to arrive, forced the swarm of fugitives on the ambuscade set up by General Green. The latter picked up all that had escaped his lieutenants. There were more than one hundred men hors de combat but he 
withdrew, taking with him two cannon and nearly five hundred prisoners.

J. Irvine Dungan, who was a member of the Nineteenth Iowa, and participated in the battle, was captured and sent to Tyler, Texas. He gives a brief notice of his eseape in his "History of the Nineteenth Iowa Regiment." He states that Col. J. B. Leake protested about the insecurity of his position at the Norwood farm, and that General Vandever was sent out to investigate, and reported the position as being. dangerous for Col. Leake's force. But General Herron, who was then in command of the division, would not consent to a new position. On the 28th of September things were looking so serious that Col. Leake on his own idea of the insecurity of the location at Norwood's farm, moved to the Stirling farm.

The infantry of the command made a gallant defense, and if the eavalry and mounted infantry had stood their ground, or had charged Mouton's brigade, which was then under the command of Col. Henry Grey, the result might have been different, as in that event most of Col. Leake's command might have eseaped eapture. Or, had information of General Green's advance in the morning been given to General Dana, then in command at Morganza, the Federal forces combined might have taken nearly all of General Green's forces prisoner, on account of his limited means of crossing the Atchafalaya River.

The men of the Nineteenth Iowa fought to the limit, and only surrendered singly or in squads, and some of them had to be disarmed by the Confederates before they would surrender.

The Galveston News, a Confederate paper, gives in its issue of the 20th of October, 1863, the following account of this battle:

According to the plans, Lieut. Col. Jas. E. Harrison, commanding Speight's Brigade, was to bring on the engagement with the enemy's position, four miles in the rear of their cavalry. Colonel Gray was to hold Colonel Mouton's Brigade two miles above in the direction of Morganza, to meet any reinforcement sent to the enemy from that direction. While one battalion was to follow Harrison in supporting distance, Harrison was conducted by a guide who gave but little idea of the country. 


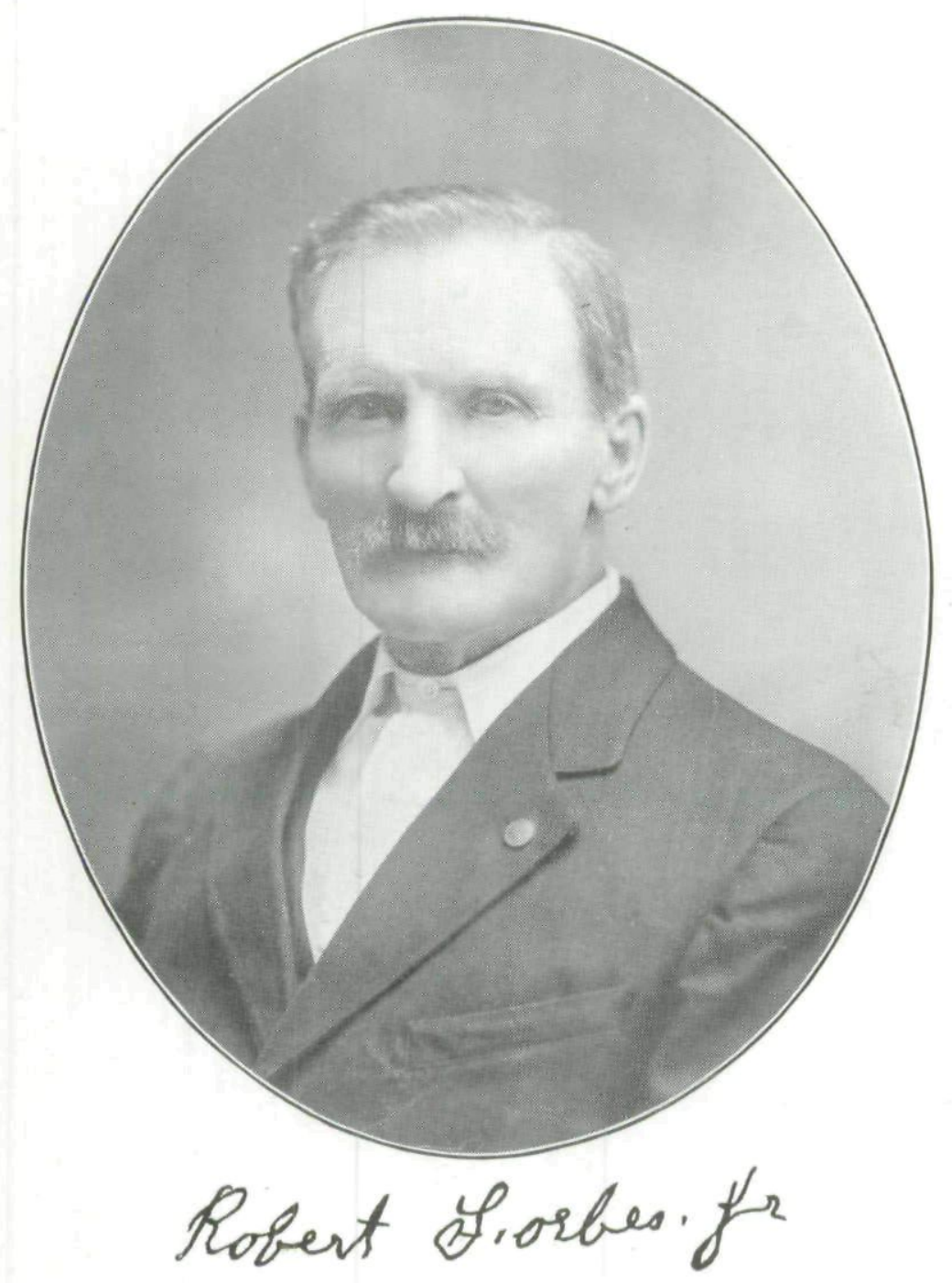


Harrison attacked their rear about half past 11 o'clock, on the 29 th of September. His position was almost as strong as though it had been made for the purpose. He was covered on every side by ditches, embankments, fences, and levees, with a large sugar mill on his rear in addition to a large ditch and fence, inside of all this there was large negro quarters in regular streets. His force consisted of two regiments and a battalion, in force much stronger than Speight's Brigade, the latter in advancing on him had to pass through a canefield covered with vines, which while it afforded no shelter, embarassed our troops very much. This advance was made under a galling fire from his entire force covered. $\mathrm{He}$ was driven from the sugar mill and first ditches to the first row of negro houses where he contested every inch of ground. Harrison made him change front by flanking him, forcing him from street to street till he was forced over the levee when he changed his front, face by the rear; here he fought desperately, using two pieces of artillery with great effect.

Harrison ordered one of the pieces to be taken, which was captured and retained during the action. The enemy now attempted to flank him, by a movement on his left by marching rapidly behind a high levee. The attempt was discovered through a gap or break in the levee. Our men were now inside, the enemy outside. . . .

While he was attempting this, Harrison flanked him with his right and with a division held his flanking column back when his left gave way, retreating across an old fleld covered with high weeds. At this moment, Major Boone commanding Weller's Battalion of cavalry came up with a gallant charge on his right flank, and completed the rout. The supporting force never reached Harrison, and the officers and men fought gallantly; men could not have done better. . .

We lost twenty-seven killed and eighty wounded; and captured of the enemy four hundred and thirty-two privates and non-commissioned officers, and twenty-nine commissioned officers.

General Dana sent out a detachment under the command of Capt. Jourdan, under a flag of truce, and buried the dead of both parties.

Robert Forbes of Company I, Nineteenth Iowa, now residing at Keosauqua, Iowa, made his escape during the confusion of the surrender of the detachment. He hurriedly left the scene of the encounter, and keeping in the high weeds and eane, safely eluded the enemy. While making his way in the direction of Morganza, he encountered a man on horseback, 
dressed in Confederate gray, whom he made prisoner, and walked him into Morganza. The man whom he captured proved to be Lieut. Col. Guest, either of the Fourth or Fifth Texas Mounted Infantry, then serving as dismounted. Forbes turned his prisoner over to the commander of the post at Morganza, together with his horse, which was a fine one, and his trappings, including a silver mounted Colts revolver. Forbes asked to keep the revolver as a trophy, but the officer in command would not permit it.

In this engagement the Union forees lost as follows: killed, 2 officers, 14 enlisted men; wounded, 5 officers, 40 enlisted men; captured or missing, 21 officers, 433 enlisted men, making a total of 515 men. ${ }^{1}$

The prisoners were taken across the Atchafalaya River and left standing in line all night in the rain and mud, without food and without even a chance to sit down or take any rest. As they had been hurried away after eapture, they had had no opportunity to secure either elothing or food.

When morning eame the Confederates issued to the prisoners flour for their only ration. The only method of preparing it was to mix it in muddy water, roll the mixture on the end of sticks and bake it by the fire. Some of the men might have made their escape, but the Confederate officers promised from the first to parole them.

The next morning the prisoners were started for Alexandria, La., eighty miles away. On this march nothing unusual occurred other than hard tramping, with little to eat and no sleeping accommodations except the bare ground. On arriving within twenty-five miles of Alexandria they were hauled to that place on a cotton tramway, aboard small flat cars. This was slow going but better than walking. Arriving at Alexandria they were quartered in the court-house, and had a ration of corn bread and cooked beef issued to them.

The Confederates repeated their promise to parole the prisoners, but next morning they were started on foot for Shreveport, La., one hundred and eighty miles distant, under escort of a detachment of eavalry. The first town through which

${ }^{1}$ Rebellion Records, ser. 1, vol, 26, pt. 1, page 325 . 
they passed after leaving Alexandria was Mansfield, where a Major of the Mexican War, a man with a wooden leg, and who appeared to be an independent and leading eitizen, brought to the prisoners a wagon load of cooked sweet potatoes, and another wagon load of cooked meat, all of which eame in mighty good play.

The party rested at this place two days and were visited by a large number of women and children, who were anxious to see the Yankees. One little girl said to her mother, "Why, mamma, I don't see any horns on the men." A very aristocratic elderly lady tried to argue the questions of the war with the prisoners, but with poor results. The boys were in a situation in which they eared more for their immediate comforts than for the questions of the equity of the war. Really, the only argument they had to present was with a musket, not against the women, of course, but the army which represented their side of the case.

The next town was Mackintosh, where the following incident took place. A man brought a cart load of provisions to the prisoners' eamp to sell. The boys erowded around the eart, which had a dump bed, and some one slipped out the toggle-pin, whereupon the load was dumped on the ground. This frightened the mule attached to the cart and caused it to run away, and before it could be eaught and brought back the provisions were "non est."

Shreveport was the next town at which a stop was made, after leaving Mackintosh. The party of prisoners arrived there on Saturday, Oct. 17, 1863, after nearly a two weeks' tramp. Nothing happened on the march beyond the usual hardships incident to men in this situation. The fare was corn bread and sweet potatoes, with a little meat. The sleeping accommodations were the vare ground, without blankets or covering of any kind. Arriving at Shreveport, the prisoners were marched through the streets; a performance very humiliating to them as they were nearly naked and very dirty, having had no opportunity to change their elothing or take a bath since the day of their eapture. 
The boys had behaved badly here, some of them having used vile language while marehing through the streets. They were called into line by a Confederate major, an ex-steamboat mate and captain, who had assumed command of the prisoners and escort. He threatened them with death and other dire punishments, unless they conducted themselves in a little more decent manner. The major announced that the prisoners were to be taken to Tyler, Texas, and that there they would have good quarters, good treatment, and would shortly be paroled.

About November 1, 1863, the party reached Tyler, Texas. Tyler is situated some one hundred and twenty-five miles from Shreveport, a little southwest and about two hundred miles north of Galveston. The prisoners' eamp was located in the piece of timber near the town, where was a spring forming a branch which ran through the grounds. The officer in command of the camp, a Colonel Allen of the Confederate army, had been a preacher in the Methodist Episcopal Church South. He was really a very good man, and as long as the prisoners were reasonable in their conduct and demands, they had no trouble. ${ }^{1}$

Permission was given the men by the Colonel to go outside of the camp to eut fire-wood and secure something extra to eat. On these expeditions they were placed on their honor. Axes were furnished them and they were allowed to build suitable houses in which they could pass the winter in reasonable comfort, although the winter of 1863 and '64 was extremely cold, even in Texas. The prisoners, however, were not retained here all winter.

The food here was eorn meal and beef, cooked by means of old-fashioned skillets and ovens, borrowed from the guards, as had been done all the way from the place of capture.

The boys found $400 \mathrm{U}$. S. Marines at Tyler who had been there thirteen months. They had been eaptured at Sabine Pass in the naval encounter with the Confederates. The boys fraternized with the Marines and the two parties got along nicely together.

\footnotetext{
${ }^{1}$ Colonel Allen was assassinated soon after the war. He was killed from ambush by a rifle. The authorities never ascertained by whom or for what cause.
} 
An imaginary line, ealled the dead line, had been established about five feet inside the outer line of the camp. In bringing their fire-wood to camp, the prisoners stopped at a safe distance and pitched it across the dead line. Orders were striet that no prisoner should approach the dead line. A man reported for guard duty shortly after the arrival of the Nineteenth Iowa, who made threats that he never would be satisfied until he had killed a Yankee. Of course this was not a soldier from the firing line, but a home guard. Well, soon after he took his place as one of the guards, while some of the boys were pitehing wood over the line of the camp, he fired his musket, the ball from which killed one prisoner and passed through the arm of another. Both these men were receiving the wood and were on the inside of the camp.

A rush was made by a lot of the prisoners for the man who had performed this dastardly act, and he would have been torn limb from limb had not their own officers interceded for milder measures. The Methodist Colonel in command called a court of inquiry and after hearing the testimony from both guards and prisoners, turned the man over to the eivil authorities of the State of Texas. What was finally done with him the prisoners never learned.

In the main the prisoners were fairly well treated here. This was largely owing to the Methodist Colonel in command of the camp, who was a kindly man and seemed to have a happy faculty of getting along with everybody. They were often out on their honor and were sometimes late in getting back to eamp; but most of the tardy eases were condoned by the officer on duty.

The shanties or cabins built by the prisoners were made of pine saplings and roofed with pine boughs. Such roofs kept out the wind and cold, but would not keep out the rain, of which there was an unusual amount that season for that latitude. Fire-places were built in the cabins, small logs being used for this purpose, and they were plastered inside with mud to make them fire-proof. Stick chimneys were built, coated with mud on the inside in the same way. Their Confederate hosts furnished them with boards out of which were 
constructed sleeping bunks. While building the cabins the prisoners were allowed great liberty, going and coming without guards.

After completing their shanties the prisoners were employed in building a stockade around the camp. This was made of logs set upright, four or five feet in the ground, the larger logs being split. The height of the stockade was about twelve feet and a narrow platform about eight feet from the ground ran all around the inside, for the use of the guard while on duty.

A number of the prisoners made their escape from the eamp at Tyler only to be recaptured, some of them within less than fifty miles of the Mississippi River, but the most of them after having gone only a short distance from Tyler. Bloodhounds, a meagre population and seareity of food, combined to defeat the efforts of the men who tried to make their escape.

Near the end of December the prisoners taken at the battle of Stirling's farm, consisting of the Nineteenth Iowa, Twentysixth Indiana and the Artillerymen, were paroled in order to save guarding, and sent under escort of a squad of eavalry to Shreveport. There their paroles were withdrawn and the prisoners confined in a camp four miles below Shreveport, and about one mile back from the Red River. Here, as at Tyler, the prisoners were permitted to build eabins for shelter, boards being furnished by the Confederates for roofs and bunks. The officer in command of this eamp was Colonel Theard. He was ordered to the east of the Mississippi, and in conversation with some of the prisoners said he was dissatisfied with the way the war was being eonducted, and that he would desert the army when he reached a point convenient for the purpose, and go to his home in New Orleans.

After the successful eseape of the seven prisoners to whom he had thus expressed himself, they met Colonel Theard at his office in New Orleans, when on their way to rejoin their regiment.

The paroles of the prisoners having been withdrawn, as stated above, two separate parties determined to effect their 
escape and immediately began preparations by storing up what food and clothing they could procure. It happened that two Confederate eouriers, who visited the camp bearing dispatches, hitched their horses near the camp while they delivered their dispatches to the Colonel at his headquarters. A double roll of home-made blankets was fastened on the back of each courier's saddle. Two of the prisoners who were preparing to escape, succeeded in evading the camp guards, eut away the blankets and got back undetected inside the guard lines. The blankets were secreted and the seven prisoners used them during their subsequent journeyings while making their escape; these were the only covering they had.

The parties sold the brass buttons off their clothing, taking pay in Confederate money. The South was literally without buttons for their ordinary wearing apparel, while the uniform clothing was very frequently found equipped with buttons aequired from Union soldiers. They bought all the fresh beef they could procure, which they dried (jerked). This they stored away with what corn bread they had been able to obtain, ready for the break for liberty.

There was a depression in the ground, a shallow ravine just inside of the lines. It had been planned, on pretext of imparting some news to one of the guards, to attract his attention, and hold him with his back to the ravine, until the other guard had reached the ravine and turned, so as to get them back to back. Fires were also built near the guard line on each side of this ravine. It was expected that the reflection from these fires would have a tendeney to blind the guards. The break for liberty was made on the night of February 25, 1864. In walking their beats, the guards met at the ravine above alluded to, where they turned and walked back to the next post. At six o'clock in the evening the guards were doubled. It was therefore necessary for the prisoners who had made preparations to escape, to make the attempt between dark and six o'clock. The interval was only about fifteen minutes, at that season of the year. Some of the men who remained at the camp and were in the secret, were to keep 
watch, and cough as a signal the minute the conditions wers favorable.

The favorable moment eame, the signal was given and the party of seven marehed in single file safely out of the prison camp.

Six of the men were members of Company H, Nineteenth Iowa, viz.: Sergeant W. W. Byers, afterwards a lieutenant, still residing at Chautauqua, Kansas; Corporal J. F. Daugherty, still residing at Keosauqua, Iowa; Privates: E. P. Taylor, living now at Greenfield, Mo., J. T. Paxton, residing at Milton, Iowa; Jonathan Nixon, who died at Keosauqua, Iowa; and Simon Bodkin, now living at Wellington, Kansas. The seventh man was Sergeant J. S. Ragsdale, now living at Birmingham, Iowa, who was afterwards promoted to First Lieutenant of Company I, Nineteenth Iowa.

The timber was very thick near the guard line and there was considerable underbrush. It had been agreed that the men, leaving the eamp one by one, should meet at a certain deformed tree some distance from eamp. This they did and traveled down the river, crossing a creek on the line of march, which was so deep with quick sand that part of the company barely eseaped drowning.

The night before, Ragsdale and Byers, while waiting at the corner of the camp where the path led to the spring, for their turn to get water, fell into conversation with one of the guards named Sledge. This man announced himself to Ragsdale and Byers as a Union man at heart and urged them to make their escape. Becoming convinced that he was really what he pretended to be, a friend, the two men confided to him the secret of their intention to attempt an eseape the next night, whereupon Sledge promised to help them. He directed them to go down the river about six miles until they should find themselves opposite a certain house, on the plantation of a Confederate major, where his brother-in-law, a $\mathrm{Mr}$. Green, resided. Green was a Northern man, Sledge explained, and devoted to the Union cause. He was, however, the most suceessful farm superintendent and "nigger" driver in that part of the country, and because of his value 

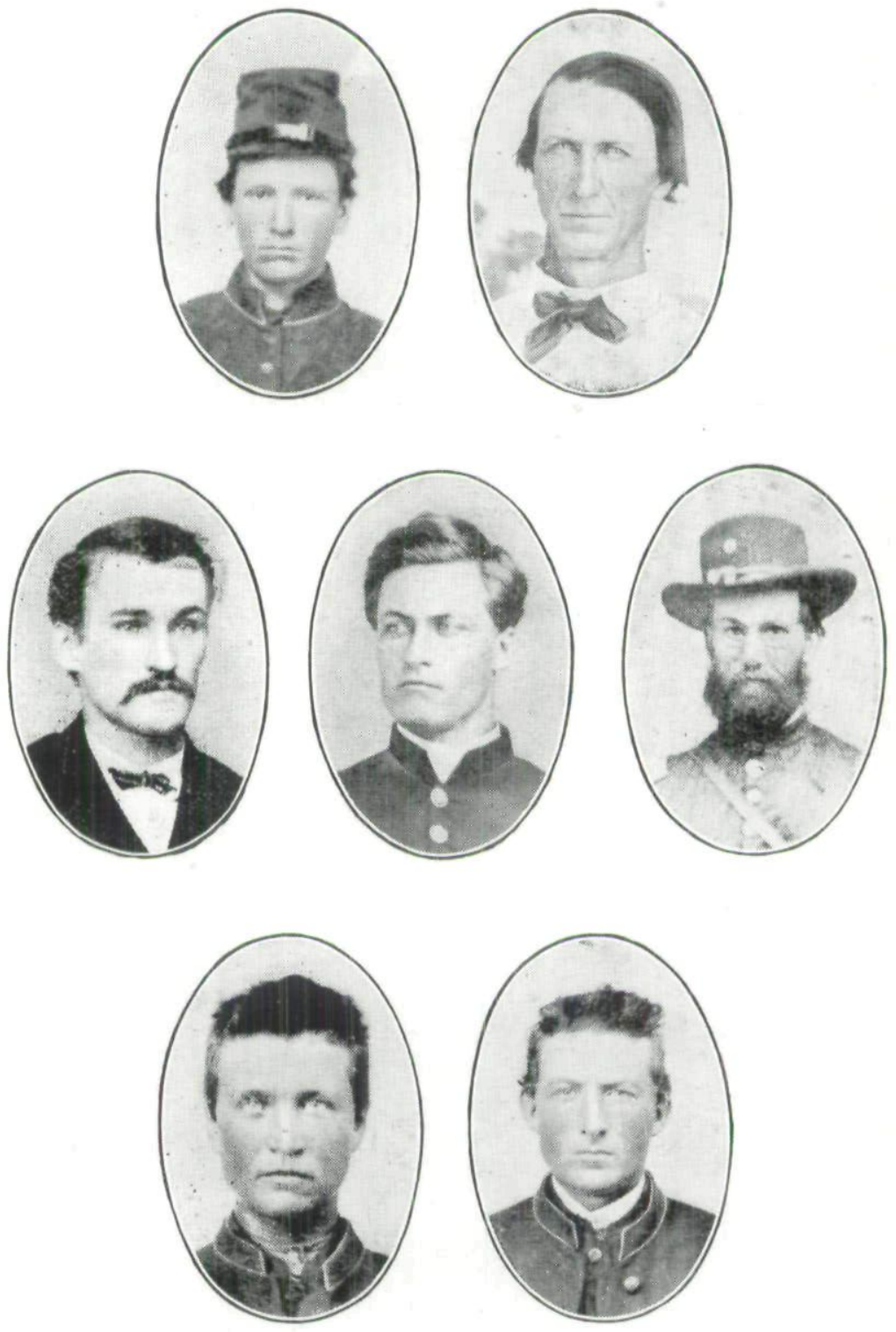

E. P. TAYLOR

JONATHAN NIXON
J. F. PAXTON
SIMON BODKIN
J. S. RAGSDALE
J. F. DAUGHERTY
W. W. BYERS 
in these respects, and through political and personal influence, he had been allowed to remain South and keep out of the Confederate army. It was Sledge's intention to go to his brother-in-law's house next morning as soon as he should be relieved from guard, and he promised to arrange with Green to help them get away.

After wading the ereek already mentioned, and a swamp which was neck deep, the escaping party hid in some woods and tree tops opposite Green's house for the remainder of the night. When daylight eame, they saw a negro on the opposite bank of the stream, to whom they signaled their wish to cross. The negro came over in a boat. It had no sooner struck the landing than all seven of the men rushed down the bank and boarded it, considerably alarming their black ferryman. He suspected who they were, however, and rowed them across, cautioning them against danger of Sledge's betraying them and admonishing them to be eareful, as it was pretty dangerous around there.

Having safely crossed the stream the men hid in the woods, eovering themselves securely with brush-wood, and there they remained all day. They could hear the bloodhounds baying on the other side of the river, and knew by the sound that they were being hunted by the Confederates.

When night eame, two of the party made their way to the vieinity of Green's house and inquired of the negroes if their master was at home. The negroes found him and when he came out he told the men that Mr. Sledge had been there the morning before, and that everything was all right. He then sent a negro with two men to a point above the house for his skiff, telling them to row it down past the cotton-gin, about a mile below to a plantation, where they would find a yawl large enough to carry their entire party. Accordingly two of the men got into the skiff and following the instructions given by Green, succeeded after some searehing (it was then after dark), in discovering the yawl. It lay in a bayou, or ereek, on the north side of Red River. Meantime Green, after supplying them with bread and meat, piloted the five men down to the bayou, where they joined their companions. Green's 
skiff was fastened to the bank, and the seven men boarded the yawl and proceeded down the river until daylight.

For three nights they continued their journey, floating down the stream, hiding in the timber back of the plantations in the upland during the day and concealing their boat by sinking it in some safe place.

One or two incidents in their night journeyings were somewhat exciting. Coming around a bend in the river, on one occasion, they found themselves looking full into a Confederate camp. Just beyond a town was plainly to be seen. There was no going back, of course. The banks, luckily, were high and steep, and they thrust the boat close to the shore and floated past the danger points unmolested and unseen.

The river was full of snags and drifts, and the nights being very dark, considerable trouble was experienced in steering clear of them. Rounding one of the many bends in the river, the man in the bow of the yawl, who was the lookout, seeing that they were about to strike a drift, eried out, "right" when he should have said "left." In consequence of the false directing, the boat ran against the drift sidewise, partly overturning it. In their efforts to save the provisions, the men got a thorough wetting, but the boat was finally righted and they floated on. It was an old and leaky affair, and after running on the drift, leaked of course worse than ever.

On the fourth evening, having passed the hours of daylight in hiding, as usual, and coming to the place at which the boat had been sunk for concealment, no boat was found. This eaused the party great alarm, for it seemed a pretty sure prelude to their capture. Careful search was made at once for the missing eraft, and to their decided satisfaction it was found hidden in a clump of willows and bailed out ready for use. Some vagrant negro doubtless had found the boat by accident, raised it and concealed it with intent to take it away at his convenience. The men were not long in getting under way and were greatly relieved when out of gun shot of the locality. 
After floating a part of this night, it was decided by a vote to abandon the boat and strike across the country. Navigation had grown more hazardous for various reasons, but chiefly on account of the increasing frequency of Confederate craft on the river. Accordingly the boat was abandoned and the land journey resumed. As before, the men traveled by night, being guided in clear weather by the north star and in cloudy weather by the bark on the trees.

As a means of defense each had provided himself with a cane, in the shape of a hardwood elub, with a ball on the larger end whittled out with their pocket knives. These clubs were hardwood sprouts with the root attached, the roots grubbed out of the ground. For covering when lying down, there were the three blankets which it will be remembered had been "borrowed" from the saddles of the horses of the Confederate couriers before leaving the prison eamp. The clothing of the escaping men, including their shoes, was badly worn. They could not have a fire, and in eonsequence suffered greatly from the rain and eold.

Most of the streams were crossed with the aid of rafts, which were made by binding together fence rails and pieces of drift wood by means of vines. The food and clothing were put aboard the rafts, the men, those of them who could, swimming behind and pushing it across, the others holding on. The ferrying was a matter of considerable time as at least three extra trips had to be made.

For several nights the journey was pursued without incident or adventure. But one night while traveling the main road, they were startled by the barking of a dog, which was immediately answered by a number of others, and presently the unwelcome discovery was made that they were on the edge of a town on the Red River. Lights were displayed in several windows. Retreating at once to a safe distance, they made a circuit of the place, through the woods and fields, eoming upon a sheet of water, which proved to be Lake Bistineau, which they skirted until they again struck the main wagon road on the river east of the town. While thus skirting this lake the travelers eame to a Spanish settlement. The 
men of the place were all absent, either in hiding or in the Confederate army. The women could not speak English, but from the appearance of the travelers they had no difficulty in reaching the conclusion that they were in want of something to eat. Accordingly they gathered some corn from the shocks in a nearby field, husked it and shelled it, and ground it in a stone mortar with a stone pestle, Mexican fashion. From the meal they made bread and gave to the men. Expressing their grateful appreciation as well as they could, the men journeyed on.

A large eamp was passed, consisting of a Confederate wagon train with supplies for the army. Giving the camp a wide berth, they eame to a point where the lake had its outlet into the Red River. This proved to be wide and deep, just how wide they were unable in the darkness to determine, as the growth of trees was dense on both banks and hung over the water. Fortunately they found a good-sized ferry-boat, of unusual length, and built after the plan of a barge, with long poles for propelling it. Boarding this boat they proceeded to use the poles vigorously until they thought they were under sufficient speed to be carried to the other shore, when the poles were dropped and they waited for their craft to make the bank. It was some time before the boat struck and the men had become alarmed, when finally one corner struck the opposite shore near the outlet to the main river. The men in front sprang ashore, the boat rebounded and those farther back had to leap into the water. It was with the greatest difficulty that they reached the shore and saved their provisions. The ferry-boat floated out into the main river and was soon lost to view. Its loss was no doubt a serious ineonvenience to the Confederates in their communication with the army. The party continued to journey by night and pressed forward with the utmost speed their strength would allow, fearing to be eaptured and held for the loss of the ferry-boat, which no doubt would have been the severest penalty.

The distance between here and the Washta River was made without incident of note, except the meeting of rebel cavalry 
squads oeeasionally. They were enabled to avoid them by means of one of their number walking a distance ahead, and giving a signal of alarm by striking two eanes together. When the alarm was given all would leave the roadside quietly and lie down until the enemy had passed. The pine forests through which they were now passing were thinly settled and but little food could be obtained. On reaching the Washta just after dark, in a thick fog, voices were heard on the other side. Hallooing lustily, they were answered by a negro, to whom they eried out "Over!' This request was complied with by the negro eoming over in a flat, capable of earrying four persons, thus requiring two trips. The negro charged fifty cents each for his services. He was paid in part, the travelers promising to pay the balance on their return next day. They represented themselves to be Confederates, belonging to Jones' brigade, which the negro had informed them on the way over was in eamp a little way down the river. The fog and darkness prevented the negro from seeing how little or much they looked like Confederates. Owing to the proximity of "Jones' brigade" the party made as great a distance as was possible in their weakened condition, darkness, fog and the uneven swampy ground over which they had to pass. After they had traveled as far as they could for weariness - three or four miles-they threw themselves upon the cold ground to rest and sleep as best they could until daylight, for it was exceedingly hard to make headway in the darkness of the night.

The journey was resumed next morning due east. The day being still foggy and overeast with dark clouds, their eourse could only be determined by the moss on the trees. The Bayou Boeuf was soon reached and a very large stream, too, for a bayou. There were no signs of eivilization here whatever, and the question of erossing the stream weighed heavily on the minds of the party. They, however, naturally started up stream, the source of which was apparently northeast, thus enabling them to increase the distance between them and the eamp of Jones' brigade, which was very much to be desired. The men were so engrossed in the matter of 
finding a crossing or something to cross on that they did not observe a gradual but continuous bend in the bayou to the northwest, thus eausing them to eurve in their line of travel. After pursuing this course for perhaps two miles they heard the tinkle of a cow bell away to their left. This was a welcome sound, for they were almost famishing from hunger. Hoping to find some trace of human life and habitation, they left the river at right angles, in the direction of the sound of the bell. After winding their way through a swampy forest wilderness of dense growth, they emerged into a small opening where the sun could penetrate and grass could grow. Here they found the bell and the cow that tinkled it. This was encouraging, for they thought something to eat could not be very far away. Casting about a little further the party discovered the exact spot where they had lain the night before. This was a little too much, as they had not realized they had made such a circuit. A council of war was held at once. There was not even a path or anything to show that the cow belonged in the direction the party wished to proceed. Every feature of the country on their course was wilderness and desolation. To go far into this wilderness without food would mean their inability to get back. Suggestions to go to Jones' eamp and give themselves up were made and considered, and other features and conditions were gone over, and discussed. But the thought of home and loved ones was all prevailing, and a resolve to make one more effort, "sink or swim, live or die," for home and native land prevailed, and the party started again for the Bayou Boeuf.

Searching about for a means of getting over, they discovered what appeared to be a section of a fallen tree. On closer inspection the tree trunk turned out to be an alligator, of the largest size. The creature erawled into the water, but as it took up a position close to the shore and refused to be driven away by vigorous and repeating clubbing, it was decided not to attempt to cross the stream at that point. They therefore followed the river or bayou up for about two miles to an abrupt bend, where they came upon a well-worn path, leading directly back from the river to another bend at right angles 
with the first. From this point they had a view of quite a nice plantation on the other side. Raising their voices in loud halloos, a negro finally responded, eoming down to the river bank. He came over on a raft and ferried the party across. The overseer and all other white persons were absent from the plantation, and the negroes furnished the travelers with a good supply of provisions. The night of that day they slept in a swamp, after tramping and wading in swamps and bayous all day. The following morning a small stream was reached, which was greatly swollen from the recent rains. While constructing a raft from a pile of lumber on the bank, a troop of Confederate cavalry was seen passing on the road near by. Fortunately the troopers failed to discover them, or if they did, concluded they were natives. At any rate they paid no heed to them. Finishing the raft, the party erossed the stream and journeyed in an easterly direction.

In the course of this day's journey, they eame to a nice looking plantation. The peach trees were in full bloom, making a pretty sight. Approaching the house, the men represented themselves as Confederates; but the inmates there found, a man and his two sisters, saw through the pretension, and insisted that they were Northern men. As the folks appeared friendly, the travelers finally confessed the truth about themselves, admitting they were Federal soldiers, escaping from imprisonment. Therefore they were invited in, the people offering to keep them in hiding for the present, and to furnish a guide as far as the Mississippi River, when they should be ready to go on. The Mississippi, they said, was about twenty-five miles distant.

The men declined the invitation and offer, but accepted with gratitude a generous supply of provisions. Proceeding on their way, they had hardly left the plantation behind, when a mounted conseript passed near them. As his path led through thick timber, the Confederate was kept so busy dodging the low hanging branches that he had no eyes for anything else, and consequently the men eseaped being seen.

The food obtained had greatly strengthened all the members of the party, and their progress was now rapid. Having 
had such a narrow escape from discovery by the conseript soldier, they were naturally inspired by the incident to increase the distance between themselves and that locality with all possible speed. At dark, another small stream was reached, turbulent and much swollen. It was decided not to attempt a crossing that night, so they camped near its bank. The next morning it was found that the water had subsided and they crossed with little difficulty.

The following night the men slept on the cold, wet ground as usual. Morning coming, the march was taken up and after traveling about two miles through heavy forest, with thick underbrush and briars, they reached the Macon River. Like the other streams which had been met in their journeyings, the Macon was much swollen from the spring rains. There was a large plantation just above the point at which they had struck the river. The place not being favorable for effecting a crossing, the party went back some distance, skirting the plantation, with the intention of striking the river above. When the circuit was about half made, however, the baying of bloodhounds was heard, and the creatures could be perceived, apparently on their trial. Appearances were in accordance with the facts, for when the hounds reached the river where the men had paused, they could be seen hunting around for the trail. Picking it by the aid of their keen seent, they started back on the tracks of the fleeing men.

Without hesitation the party struck across a field for the river, and hurriedly put together a raft of rails procured from the fence near the river, binding the rails with vines which fortunately grew near by. The frail raft was immediately launched and while the three men who were not swimmers, supported themselves in the water by holding to the raft, the men who could swim pushed the raft across the stream, though Ragsdale, being a good swimmer, struck out boldly alone for the opposite shore, with what provisions he could carry along on his back. In midstream he was seized with cramps, and came near drowning, but he struggled on and made the bank safely. The main party with the raft 
also crossed in safety. As they elimbed up the river bark, they looked back and saw the pursuing bloodhounds standing at the water's edge opposite. They now felt themselves comparatively safe, knowing that bloodhounds ean not keep the seent through running water. Their conviction was strong that they were being followed. Naturally, the suspicion was in their minds that the friendly man and his two sisters, who had been so solicitous to entertain them, might be responsible for their pursuit. But whether they were or not or whether they really had been seen by the trooper in the woods, it was of course impossible to decide.

Continuing the journey, after proceeding some two miles, they came upon an abandoned cavalry camp, with the campfire still smouldering, and an amount of corn and cornbread scattered around. Gathering up a quantity of the bread, the men went on. The journey now lay through eypress swamps with their slimy logs to eross, eane-breaks, brushwood, and grape vines. Traveling in such a country was not exactly a pleasure jaunt, but all haste possible was made and at length the Tensas River was reached. This inlet stream to the Ma. con the men were anxious to place between themselves and the bloodhounds.

A large drift of logs lay near the place at which they had struck the stream, and from this it was determined to construct a raft. On walking out on the drift, however, the discovery was made that many of the supposed logs were alligators. The men tried with elubs to drive the saurians from the locality, but without success. While the raft was being put together in the edge of the river, they formed a circle around the place, watching the men as they worked. It was necessary to make no less than six trips across the stream, as the raft was only strong enough to bear the weight of two men at a time, and at each journey the alligators followed the raft, keeping close watch, apparently expecting some one to fall overboard.

Mr. E. P. Taylor, now of Greenfield, Missouri, one of the squad of escaping prisoners, has written an account of the 
adventures of himself and comrades in which many incidents of an instructive kind are narrated, from which we quote the following:

Taylor and Byers, leaving their comrades in hiding, applied at the door of a house and asked for food. The elderly woman who answered their knock, said she would bake them some bread. They waited. Her first move was to go out and get some corn, which she brought in and husked. The men supposed that she was going to feed a horse which stood near at hand. But she began shelling the corn off the cob. Seeing no sign of any bread being made, the men asked the woman how soon she would get at her bread-making. She replied, as soon as she got the corn shelled and ground. They concluded they would not wait. As they were leaving they saw a hand corn-grinder and concluded that the woman would really have baked them some bread if they could have waited for the long preliminary process. This incident may indicate the primitive way in which many of the natives of that section of the southwest lived.

At another time, night having fallen, they stopped at a house where supper was served for them. There was no table in the house, but outside the door was a contrivance that answered the purpose, made in the following way: four forked sticks had been driven into the ground, slender poles laid in the forks, and on these split boards or "shakes" were laid. Now for the table service,-it consisted of two broken plates, one knife with a broken blade, and one with a broken handle, one two-tined fork with a broken tine, and to match the knife another fork with a broken handle. Rye coffee was served in two utensils, one a gourd cup, cracked, and the other a tin cup minus a handle. The coffee-pot had no spout. The only sound and whole article was the skillet. In this they cooked first the bread and then the meat. The meat was dried beef and it was very good. They bought some of it to take with them and also a good-sized cake of corn bread. In spite of the rudeness of the arrangement, the kindness of the people was genuine.

The escaped prisoners were now within fifteen miles of the Mississippi, and realizing that the nearer they approached their own line, the greater was the danger of recapture, they pushed on with fear and trembling. When Bruins Lake was reached, which is about fifty miles below Vicksburg, the men, supposing it to be the Mississippi, on approaching the bank, in their enthusiasm very indiscreetly gave three cheers for the Father of Waters. There was a small group of houses near, 
and the oceupants, hearing the cheering, came out to see what was the matter. An old gentleman approached the men and from him they learned that the body of water before them was not the main river but Lake Bruin; that the main river was five miles distant, and that to reach it they would have to go down and around the lake for the distance of ten miles. Guided by this information and feeling the situation to be critical, the party at once proceeded on its way with all haste.

As they finally approached the Mississippi, they came to a large plantation, and were informed by some negroes on the place that a Yankee gunboat was lying up the river guarding a lot of cotton. The smoke of the gunboat could be pereeived. Turning their steps now up the river, the gunboat was reached just at twilight. As the party approached, it was challenged by the sentinel on duty. To his, "Who goes there?" the response was made, "Friend without the countersign", whereupon one man of the party was ordered to advance and communicate.

The officer of the guard was ealled, and was satisfied of the identity of the travelers. The captain of the gunboat, with the paymaster, just then coming up, having been out for a walk, made inquiry as to the situation and very kindly sent the men aboard the boat. There they had an opportunity to take a good bath, and each man was supplied with a full suit of clothing. Then they sat down to supper, which included coffee, a beverage of which they had not partaken for six months.

Blankets were furnished them and they lay down for a night's rest. It seemed so much like a dream, however, the comfort and the freedom from peril, that little sleep visited their eyes.

Arising next morning, however, and having breakfast, the full realization came to them that they were indeed free.

The following day a boat was seen coming up the river, and the Captain of the Switzerland, which was the name of the gunboat which the escaping men had boarded, hailed her and transferred the eseaped prisoners to her. They were landed at Vieksburg late the next evening. Next morning 
they reported to General J. B. McPherson, who treated them kindly, inquiring very particularly into their adventurous trip in making their escape, and as to their present wants. $\mathrm{He}$ offered them transportation either to their homes or to their regiment. They chose the latter and within a few days proceeded to rejoin their regiment by way of New Orleans and Gulf steamer, to Brownsville, Texas, at which point they arrived without accident.

The arrival of the eseaping men at the bank of the Mississippi was on the 13th day of March, 1864. They had been eighteen days on the perilous journey from the prison camp at Shreveport; a time fraught with constant danger and in which they had endured great suffering. The history of such a trip should live in the annals of our country.

The gunboat Switzerland, on which the eseaping men had found refuge was what was known as a "tin elad," a merchandise boat, reinforeed with heavy planking as a protection from musket shots in the hands of the guerrillas, who infested the banks of the southern rivers during the last two years of the Civil War.

On the same evening that the seven, whose adventures have been related, escaped from Shreveport, viz.: February 23, 1864, Sergeant B. H. Rodrick and N. E. Dawson with Corporals P. H. Grant and John Terrill also made their escape. They left Red River at the start and met with nothing beyond the usual danger and vicissitudes incident to such an undertaking.

Omer Hoskins, L. B. Cocklin, L. S. Hall, J. M. Towne, Enos Rushton, Benedict Rumer, and B. F. Goodwin also escaped at different periods of the eaptivity of the regiment, and came into Federal lines at various times and places.

J. Irvine Dungan, Horatio W. Anderson and Wm. MeGregor were less fortunate. They made their eseape from Tyler, Texas, and aimed to come into our lines at Ft. Smith; but were recaptured when near that point.

They broke jail, however, in eompany with Anthony C. Johnson and Wm. Greeer, both eitizens of Arkansas, who were 
confined in the jail with them. They were eaptured again, unfortunately, near Little Rock, which was then occupied by the Federal troops, and from thence taken back to Tyler.

While confined in the prison eamp at Shreveport, H. W. Anderson made his third escape, the last of February; and although the country was covered with water from the spring rains, reached Natchez, Miss., in safety, and rejoined his regiment.

The prisoners who remained at the prison eamp below Shreveport, from whence our seven eseaped, were finally returned to Tyler, and in the first week of July, 1864, the main body of the Tyler prisoners were ordered exchanged. They marched bare-headed, bare-footed and nearly naked, under the July sun, to Shreveport, where, taking boats, they steamed down the Red River. On the $22 \mathrm{~d}$ of July, 1864, they floated out on the broad Mississippi and beheld the Stars and Stripes, feeling such a thrill of joy as only returning prisoners ean feel.

\section{TRIAL OF JOHN BROWN. ${ }^{1}$}

HON. GEORGE E. CASKIE.

The trial of John Brown did not establish any great legal principles, nor is it pre-eminent as a great legal battle, but the conditions out of which it grew were as momentous as those connected with any of the great contests which had preceded or which have followed it, and place it well up in the list of important trials.

In order to appreciate the position of the prisoner and the environment under which the trial was held, it will be well to review for a moment a few leading facts as to Brown himself.

John Brown's ancestors were among the Puritans who landed at Plymouth; in his veins mingled the blood of three sturdy races, the Scotch, the Dutch and the Welsh. For at least three generations the Brown family had been abolitionists, and John Brown, reared amongst such environments and

\footnotetext{
'Paper read before Virginia State Bar Association, August, 1909.
} 
Copyright of Annals of Iowa is the property of State of Iowa, by \& through the State Historical Society of Iowa and its content may not be copied or emailed to multiple sites or posted to a listserv without the copyright holder's express written permission. However, users may print, download, or email articles for individual use. 